\title{
Cytological Detection of Somatic Mutations in Tradescantia Induced by Ethanol
}

\author{
Rafael Villalobos-Pietrini ${ }^{1}$, Raymundo Hernández ${ }^{2}$, Ma. de los \\ Angeles Guadarrama ${ }^{2}$ and Sandra Gómez-Arroyo ${ }^{1}$ \\ ${ }^{1}$ Laboratorio de Citogenética y Mutagénesis Ambientales, Centro de Ciencias de la \\ Atmósfera, Universidad Nacional Autónoma de México, Coyoacán 04510 Méx., \\ D. F., México e ${ }^{2}$ Instituto de Biología de la Universidad Juárez Autónoma \\ de Tabasco, México
}

Accepted October 10, 1984

Higher plants provide a good material for the evaluation and monitoring of environmental chemicals (de Serres 1978). The Tradescantia assay system is one of the unique plants for testing the mutagenicity, in which many genetic end points can be established, these include chromosome aberrations in root tips, stamen hairs, and microspores, as well as somatic mutations in petals and stamen hairs (Grant et al. 1981).

Tradescantia clone 02 has been one of the most used test system in radiobiology and recently, along with clone 4430 , in the environmental mutagenesis field. An important advantage of this system is the use of color changes in cells of floral parts as a mutation criterium. Heterozygous condition for flower color was used as an appropriate genetic marker to study somatic mutations, showing blue color as a dominant character and pink as a recessive one.

The high sensitivity of Tradescantia has been tested with ionizing radiations and chemicals in gaseous forms such as atmospheric oxidants, pesticides and many commercial chemicals (Ichikawa 1971, 1972, Ahmed and Grant $1972 \mathrm{a}, \mathrm{b}$, Tomkins and Grant 1972, Underbrink et al. 1973, Sparrow et al. 1974, McNulty et al. 1977, Schairer et al. 1978). Dose-response curves of this test system have been obtained with ionizing radiations and with the chemicals ethyl methanesulfonate (EMS) and 1, 2-dibromoethane (DBE) (Sparrow et al. 1972, 1974).

Tradescantia clone 02 was used in this study to determine if solvents like ethanol, chloroform and thinner can induce somatic mutations in the cells of the stamen hair system.

\section{Materials and methods}

Tradescantia clone 02 is a putative hybrid (Sparrow et al. 1961, Mericle and Mericle 1967, Underbrink et al. 1973, Sparrow and Sparrow 1976), heterozygous for flower color and it has a wild type blue-purple color corresponding to color No. 41 Lobelia Blue and a pink or purplish-red mutant that falls into the color No. 32, Petunia Purple (Mericle and Mericle 1967, Ichikawa et al. 1969, EmmerlingThompson and Newrocky 1979) described in the British Royal Horticultural Colour Chart (1939). 
Table 1. Mean frequencies of pink mutations in Tradescantia clone 02 stamen hairs, 7 to 16 days after treatment, induced with different concentrations of ethanol

\begin{tabular}{ccccccc}
\hline \multicolumn{2}{c}{ Concentration } & & \multicolumn{2}{c}{$\begin{array}{c}\text { Pink frequency/100 hairs } \\
(- \text { control) }\end{array}$} & & $\begin{array}{c}\text { Number of stamen } \\
\text { hairs analized }\end{array}$ \\
\cline { 1 - 2 } \cline { 5 - 6 } $\begin{array}{c}\text { Liquid } \\
\text { ml }\end{array}$ & $\begin{array}{c}\text { Vapour } \\
\text { ppm }\end{array}$ & & $\bar{X}$ & \pm & S.E. & \\
\hline 0.25 & 10,123 & & 0.0815 & & 0.0233 & \\
0.50 & 20,247 & & 0.1338 & & 0.0347 & 27,976 \\
0.75 & 30,370 & & 0.4527 & & 0.1534 & 64,243 \\
1.00 & 40,494 & & 0.4735 & & 0.1753 & 65,520 \\
1.50 & 60,741 & & 0.7345 & & 0.2134 & 38,936 \\
2.00 & 80,988 & & 1.0846 & & 0.1807 & 38,251 \\
& & & & & & 25,734 \\
\hline
\end{tabular}

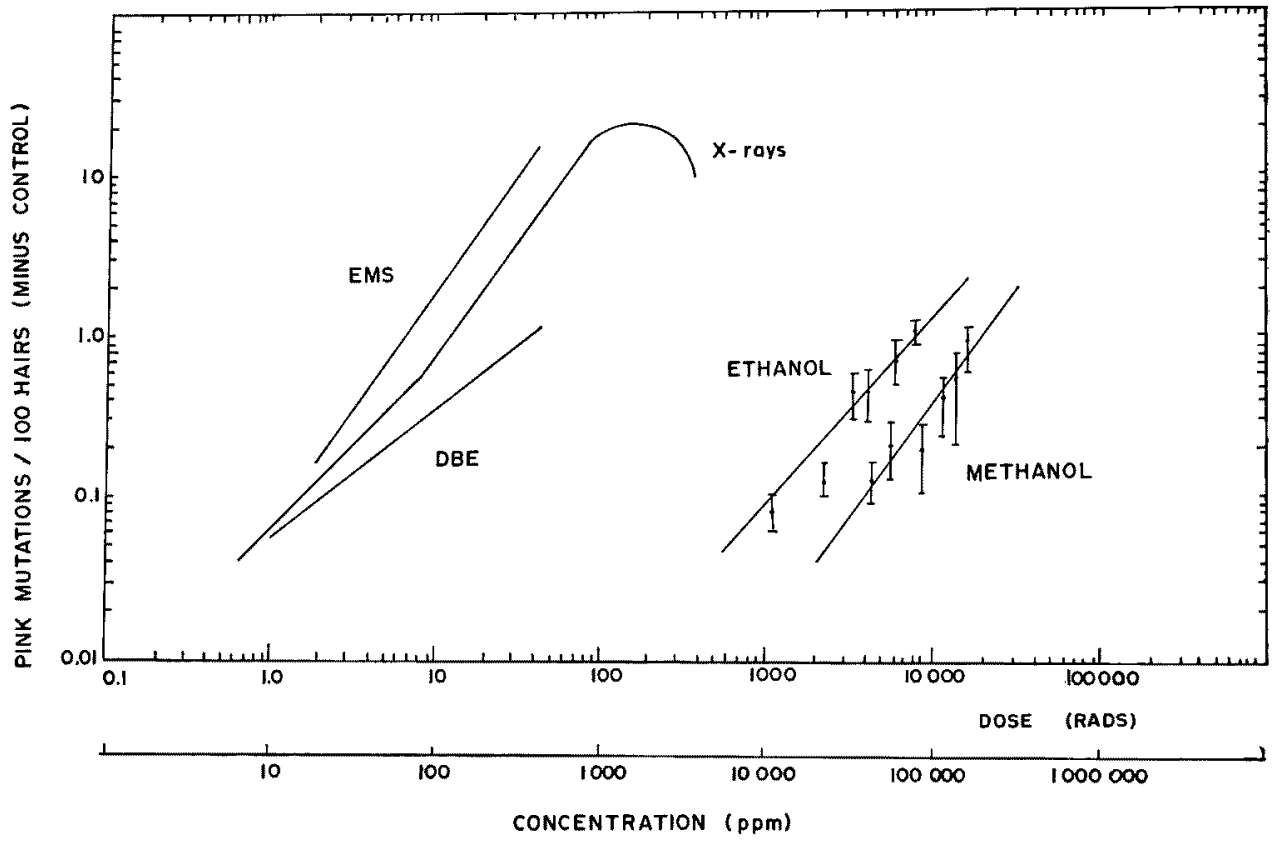

Fig. 1. Dose-response curves of Tradescantia clone 02 in a log-log system, obtained with EMS, DBE, X-rays (Sparrow et al. 1974), methanol (Villalobos-Pietrini and Hernández 1978) and ethanol.

Plants were grown in a greenhouse at the Botanical Garden of the Universidad Nacional Autónoma de México in plastic trays, with a mixture of leaf and moldy sand $(2: 1)$. For the treatment, plants were placed under laboratory conditions at $25 \pm 11^{\circ} \mathrm{C}$ and a relative humidity of $60 \%$, maintained by sprinkling them with tap water twice a week.

The evaporation kinetics of each substance was known placing $20 \mathrm{ml}$ of them in a Petri dish within a glass chamber of 9.5 liters and checking the volume evaporated at different times in a range of 6 hours. The maximum volume evaporated was as follows: $10.4 \mathrm{ml}$ of chloroform, $3.6 \mathrm{ml}$ of thinner and $2.0 \mathrm{ml}$ of ethanol. The 
chambers were sealed with silicon grease and kept at a constant temperature of $25^{\circ} \mathrm{C}$.

Similar concentrations of thinner, chloroform and ethanol were used $(0.25$, $0.50,0.75$ and $1.00 \mathrm{ml})$ besides two more of the last one $(1.50$ and $2.00 \mathrm{ml})$. The composition of thinner was as follows: toluene $(51.8 \%)$, n-hexane $(25.3 \%)$, ethanol $(12.6 \%)$, ethyl acetate $(5.9 \%)$, isopropanol $(2.0 \%)$, benzene $(1.2 \%)$ and $n$-heptane $(1.2 \%)$.

For each treatment plants were placed in a $500 \mathrm{ml}$ glass containing Hoagland nutritional solution (Hoagland and Arnon 1950, Conger 1964). In the experimental group, the plants were placed in a glass chamber with a measured quantity of the compounds to be tested and in another chamber, the control sample was placed with distilled water in a equivalent volume. The sealing of the chambers and temperature condition were similar to that explained above for substance evaporation kinetics. The exposure time for all experiments was 6 hours. The experiments were replicated once. At the end of each treatment, the plants were placed in glasses containing $500 \mathrm{ml}$ of fresh Hoagland's solution through which air was bubbled constantly. These plants were kept in growth chambers under laboratory conditions.

Cells of the stamen hairs were scored for pink events for 7 to 16 days after the treatment; this period corresponds to the maximum frequencies observed. Pink mutations frequencies were calculated from the total pink events per total stamen hairs observed.

\section{Results}

The average of pink mutations from days 7 to 16 after treatment of two replications were calculated. The frequencies of these mutations induced by chloroform and thinner were not significantly different from the control. The frequency of spontaneous mutations rate was $0.000594 \pm 0.000222$ (S.E.). The flowering was almost inhibited by concentrations of $0.75 \mathrm{ml}$ of chloroform. Thinner produced lethal effects at $1.0 \mathrm{ml}$. The results obtained with exposures to ethanol evaporated from 0.25 to $2.0 \mathrm{ml}$ are shown in Table I.

The best arrangement of data for ethanol was obtained by using the simple linear regression system, but in order to compare our results with those for EMS, DBE (Sparrow et al. 1974), and methanol (Villalobos-Pietrini and Hernández 1981), a log-log plot was used (Fig. 1).

\section{Discussion}

Due to the fact that Tradescantia clone 02 has shown high sensitivity to chemical and physical mutagenic agents, it is considered as an adequate material to compared the effects of different solvents such as methanol, ethanol, chloroform and thinner.

Chloroform belongs to the chlorinated aliphatic hydrocarbons group, largely used in the chemical industry; it has been reported to be carcinogenic in rats and mice and it is considered as a high potential hazard and as having a great environ- 
mental impact because of its high volatility and toxic characteristics (Fishbein 1976).

Thinner is one of the commercial organic solvents commonly employed as an abuse drug in México, having a predominant place in the pharmacodependency problems. Thinner is a stimulant of the central nervous system (Guzmán Flores 1975).

Ethanol is able to produced chromosomal aberrations in Vicia faba (Michaelis et al. 1959, 1962, Michaelis and Rieger 1968, Rieger and Michaelis 1972, Rieger et al. 1975, Gómez-Arroyo 1984), in Allium cepa (Sax and Sax 1966), in grasshoppers of the genus Phloeoba antennata (Manna and Mazumder 1964), and in human cells in vitro (Meisner et al. 1970, Bregman 1971, Badr et al. 1977).

In addition to the chromosome-breaking activity, ethanol disturbes the spindle apparatus which leads to an incorrect distribution of the chromosomes (Bathelmess 1957, Maguire 1976, Harsanyi et al. 1977). The mutagenic effects produced by methanol in Tradescantia, have also been described (Villalobos-Pietrini and Hernández 1981) as well as the mutagenic effects produced in Aspergillus nidulans by ethanol (Harsanyi et al. 1977), and dominant lethal mutations in CBA mice (Badr and Badr 1975), meanwhile in CD-1 mice (McGregor and Wickramaratne 1977), in Swiss mice (Chauhan et al. 1978) and in Wistar rats (Chauhan et al. 1976, 1978) the experiments with ethanol revealed negative results. In males of Drosophila melanogaster, ethanol had no effect on the frequency of sex-linked recessive lethal mutations (Vogel and Chandler 1974). Ethanol was negative in Salmonella strain TA98 in the presence of liver microsomes (McCann et al. 1975).

In relation of chromosomal alterations, in another species of grasshopper, Oxya velox, treatment with ethanol did not show increment of chromosomal aberrations (Manna and Mazumder 1964), in Swiss mice ethanol did not increase the number of micronuclei in bone marrow cells (Chaubey et al. 1977), in male Wistar rats, this alcohol had no effect on the rate of chromosomal aberrations in spermatogonias, in strains of mice having ascites tumors treated with ethanol, no elevation of chromosomal aberrations was observed (Schöneich 1966). The ethanol treatments of human lymphocytes did not affect the frequencies of aberrations (Cadotte et al. 1973). Negative results were also obtained with different alcoholic beverages (Obe et al. 1977). In HeLa cells cultures ethanol, propanol, butanol, and $\mathrm{n}$-amyl alcohol did not produce chromosomal aberrations (Obe et al. 1979).

Treatments of blood cultures with ethanol did not increase the rate of sister chromatid exchanges (SCE) (Obe et al. 1977). In cultures of CHO cells with methanol, ethanol, propanol and butanol did not induce any effect on the rate of SCE frequencies (Obe and Ristow 1977).

In this study in which ethanol, chloroform and thinner were used, only the first one was able to induce somatic mutations in Tradescantia. When high doses were applied, plants showed whitering and a reduction of flower production, in this case a higher number of plants were used in order to achieve an adequate number of flowers and stamen hairs to be scored in each experiment.

The high toxicity caused by thinner and chloroform vapours only allowed to explore a narrow range of concentrations and the pink mutations frequencies were 
observed within the range of the spontaneous mutation.

Vapours of ethanol in concentrations of $10123 \mathrm{ppm}$ did not induce mutations following the criterion that certain agents produce significative genetic damage if the mutations frequency is at least the double of that found for the control sample (Environmental Mutagen Society 1975); the range of concentration between 20249 and $80988 \mathrm{ppm}$ produced a positive response. Doses over $80988 \mathrm{ppm}$ of ethanol vapours were not applied, due to the saturation of the chamber, moreover, with this dose, physiological damage like whitering is noted. The frequency of spontaneous mutation, 0.0594 pink events by 100 stamen hairs, falls within the range given previously by Sparrow et al. (1972) and Sparrow and Sparrow (1976).

Sparrow et al. (1974) compared the effects of physical mutagens as X-rays, with chemical mutagens such as EMS and DBE, making equivalent arbitrarily $1 \mathrm{rad}$ of $\mathrm{X}$-rays with $10 \mathrm{ppm}$ of the chemical mutagen. Following the same procedure it is possible to compare the responses of the biological material throughout the plots of methanol, ethanol and the other substances mentioned (Fig. 1).

The regression lines of EMS and DBE of Sparrow et al. (1974) were recalculated including the point considered in the so-called saturation area, then the EMS slope of +2.41 changed to +1.43 and DBE slope also got down to +0.76 . Slopes for methanol and ethanol of +1.325 and +1.125 , respectively (Fig. 1), were in accordance with the expected for the combined expression of point mutations and deletions (linear and quadratic dose term) (Sparrow et al. 1972). The $\mathrm{X}$-ray values graphed logarithmically in Fig. 1 have three components, the regression line below $6 \mathrm{rad}$ has a slope +1.0 . At a higher dose the slope is +1.41 while using higher doses a saturation of the response occurs. Anywhere above $6 \mathrm{rad}$, as the slope is greater than +1.0 , the response is no longer linear but quadratic (Sparrow et al. 1972).

Comparing effects, in Fig. 1, 42 ppm of EMS, 160 ppm of DBE, 60000 ppm of ethanol, $145000 \mathrm{ppm}$ of methanol, and $8.5 \mathrm{rad}$ of X-rays produced the same effect namely 5 somatic mutations in 1000 hairs.

Although the slopes for methanol and ethanol are very similar to the EMS slope, their effectiveness is lower than that found in EMS, which is a powerful mutagenic agent, the same as DBE. They are also weaker mutagens than $\mathrm{SO}_{2}$, $\mathrm{NO}_{2}, \mathrm{O}_{3}$, freon-12 and vinyl chloride in the stamen hair system (Schairer et al. 1978).

The results support the evidence that Tradescantia is an efficient test system to detect the genetic effects of agents delivered into the environment in gaseous form, that means it represents a good genetic monitor of environmental pollution.

\section{Summary}

Tradescantia clone 02 was used as a biological test system to compare the mutagenic effects of some solvents as ethanol, chloroform, thinner in vapour forms and those previously obtained with methanol.

Frequencies of pink mutations obtained during the 7 th to 16 th days after treatment with the solvents were compared. The analysis of the results pointed out that Tradescantia was sensitive to the mutagenic effects of ethanol. Meanwhile 
chloroform and thinner vapours produced mutations frequencies similar to the spontaneous one.

According to the results, ethanol and methanol were included in the same group of mutagens, weaker than $\mathrm{SO}_{2}, \mathrm{NO}_{2}$ and vinyl chloride and specially than powerful mutagens such as ethyl methanesulfonate and 1,2-dibromoethane.

\section{Acknowedgments}

To Ms. Ana Rosa Flores and Mr. Miguel Angel Meneses for their technical assistance, and to Ms. Priscila Castillo for her kind review of the translation of the manuscript. This research was supported in part by a CONACyT grant PNCB $442 / 78$.

\section{References}

Ahmed, M. and Grant, W. F. 1972a. Cytological effects of the pesticides phosdrin and bladex on Tradescantia and Vicia faba. Can. J. Genet. Cytol. 14: 157-165.

-, and Grant, W. F. 1972b. Cytological effects of the mercurial fungicide panogen 15 on Tradescantia and Vicia faba roots tips. Mutat. Res. 14: 391-396.

Badr, F. M. and Badr, R. S. 1975. Induction of dominant lethal mutation in a male mice by ethyl alcohol. Nature 253: 134-136.

-, -, Asker, R. L. and Hussain, F. H. 1977. Evaluation of the mutagenic effects of ethyl alcohol by different techniques. In: Alcohol Intoxication and Withdrawal, Vol. IIIa, Biological Aspects of Ethanol. Edited by M. M. Gross. Plenum N. Y. pp. 25-46.

Bathelmess, A. 1957. Chemisch induzierte multipolare Mitosen. Protoplasma 48: 546-561.

Bregman, A. A. 1971. Cytogenetic effects of ethanol in human leukocyte cultures. Env. Mut. Soc. Newsl. 4: 35-36.

British Colour Council. 1939. Horticultural Colour Chart, Vol. 1. London.

Cadotte, M. S., Allard, M. S. and Verdi, M. 1973. Lack of effect of ethanol in vitro on human chromosomes. Ann. Génét. 16: 55-56.

Chaubey, R. C., Kavi, B. R., Chauhan, P. S. and Sundaram, K. 1977. Evaluation of the effect of ethanol on the frequency of micronuclei in the bone marrow of Swiss mice. Mutat. Res. 43: 441-444.

Chauhan, P. S., Aravindakshan, M., Kumar, N. S. and Sundaram, K. 1976. Does ethyl alcohol increase the incidence of dominant lethal mutations. Proc. Dunn Dobzh. Symp. Genet. 209-215.

-, - , and Sundaram, K. 1978. Failure of ethyl alcohol to induce dominant lethal mutations in Wistar rats or to synergise the effect of X-rays in Swiss mice. Mutat. Res. 53: 165-166 (Abstr.).

de Serres, F. J. 1978. Introduction: Utilization of higher plant systems as monitors of environmental mutagens. Environ. Health Perspect. 27: 3-6.

Emmerling-Thompson, M. and Nawrocky, M. M. 1979. Genetic studies of flower color in Tradescantia. J. Heredity 70: 155-122.

Environmental Mutagen Society. 1975. Environmental mutagenic hazards. Science 187: 503-514.

Fishbein, L. 1976. Industrial mutagens and potential mutagens I. Halogenated aliphatic derivaties. Mutat. Res. 32: 267-308.

Gómez-Arroyo, S. 1984. Effects produced by several alcohols on Vicia faba chromosomes (In preparation).

Grant, W. F., Zinov'eva-Stahevitch, A. E. and Zura, K. D. 1981. Plant genetic test systems for the detection of chemical mutagens. In: Short-term Test for Chemical Carcinogens. Edited by H. F. Stick and R. H. C. San. Springer-Verlag, N. Y., Heinddeberg, Berlin, pp. 200-216. 
Guzmán-Flores, C. 1975 . Neurobiología del tíner: alteraciones conductuales producidas a largo plazo. Cuadernos Científicos CEMEF 2: 49-58.

Harsanyi, Z., Granek, I. A. and Mackenzie, D. W. R. 1977. Genetic damage induced by ethyl alcohol in Aspergillus nidulans. Mutat. Res. 48: 51-74.

Hoagland, D. R. and Arnon, D. I. 1950. The water culture method for growing plants without soil. College of Agriculture Univ. of California, Berkeley Cal. Circular $\$ 347$.

Ichikawa, S. 1971. Somatic mutation rate at low levels of chronic gamma-ray exposures in Tradescantia stamen hairs. Japan J. Genet. 46: 371-381.

-, 1972. Somatic mutation rate in Tradescantia stamen hairs at low radiation levels: finding of low doubling doses of mutations. Japan J. Genet. 47: 411-421.

-, Sparrow, A. H. and Thompson, K. H. 1969. Morphologically abnormal cells, somatic mutations and loss of reproductive integrity in irradiated Tradescantia stamen hairs. Radiat. Bot. 9: 195-211.

Maguire, M.P. 1976. The effect of ethanol on meiotic chromosome bahavior in maize. Caryologia 29: 41-52.

Manna, G. K. and Mazumder, S. C. 1964. Ethyl alcohol induced sex chromosome breakage in the grasshopper, Phloeoba antennata. Naturwissenschaften 51: 646.

McCann, J., Choi, E., Yamasaki, E. and Ames, B. N. 1975. Detection of carcinogens as mutagens in the Salmonella/microsome test: Assay of 300 chemicals. Proc. Natl. Acad. Sci.(U.S.A.) 72: 5135-5139.

McGregor, D. B. and Wickramaratne, A. De. S. 1977. Does ethanol cause chromosomal aberrations? Soc. Int. Conf. Env. Mut. Edinburgh, July 11-15, Abstr. p. 89.

McNulty, P. J., Nauman, C. H., Sparrow, A. H., Schwemmer, S. S. and Schairer, L. A. 1977. Influence of X-ray dose fractionation on the frequency of somatic mutations induced in Tradescantia stamen hairs. Mutat. Res. 44: 235-246.

Meisner, L. F., Inhorn, S. L. and Nielson, P. M. 1970. Chemically induced chromatid breaks: toxigenic or mutagenic. Mammalian Chromosomes Newsl. 11: 69-70 (Abstr.).

Mericle, L. W. and Mericle, R. P. 1967. Genetic nature of somatic mutations for flower color in Tradescantia, clone 02. Radiat. Bot. 7: 449-464.

Michaelis, A. and Rieger, R. 1968. On the distribution between chromosomes of chemically induced chromatid aberrations: studies with a new karyotype of Vicia faba. Mutat. Res. 6: 81-92.

-, Ramshorn, K. and Rieger, R. 1959. Äthylalkol radiomimetisches Agens bei Vicia faba. Naturwissenschaften 46: 381-382.

-, Nicoloff, H. and Rieger, R. 1962. Influences of the EDTA on the induction of chromatid aberrations by triethylenemelanine and ethyl alcohol. Biochem. Biophys. Res. Commun. 9: $280-284$.

Obe, G. and Ristow, H. 1977. Acetaldehyde but not alcohol induces sister chromatid exchanges in Chinese hamster cells in vitro. Mutat. Res. 56: 211-213.

-, - and Herha, J. 1977. Chromosomal damage by alcohol in vitro and in vivo. In: Alcohol Intoxication and Withdrawal, Vol. IIIa, Biological Aspects of Ethanol. Edited by M. M. Gross. Plenum N. Y. pp. 47-70.

-, - and - 1979. The effect of alcohol on chromosomal structure and function. In: Biochemistry and Pharmacology of Ethanol. Edited by E. Majchrowicz and E. P. Noble. Plenum N. Y.

Rieger, R. and Michaelis, A. 1972. Effects of chromosome repatterning in Vicia faba L. I. Aberration distribution, aberration spectrum, and karyotype sensitivity after treatment with ethanol of differently reconstructed chromosome complements. Biol. Zbl. 91: 151-169.

—, -, Schubert, I., Döbel, P. and Jank, H. M. 1975. Non-random intrachromosomal distribution of chromatid aberrations induced by X-rays, alkylating agents and ethanol in Vicia faba. Mutat. Res. 27: 69-79.

Sax, K. and Sax, H. J. 1966. Radiomimetic beverages and drugs. Science 152: 676.

Schairer, L. A., Vant'Hof, J., Hayes, C. G., Burton, R. M. and de Serres, F. J. 1978. Exploratory monitoring air pollutants for mutagenicity activity with the Tradescantia stamen hair 
system. Environ. Health Perspect. 27: 51-60.

Schöneich, J. 1966. Zur Frage der Mutagenen-Wirkung von Äthylalkohol. Humangenetik 3: 84-85.

Sparrow, A. H. and Sparrow, R. C. 1976. Spontaneous somatic mutations frequency for flower color in several Tradescantia sp. and hybrids. Environ. Exp. Bot. 16: 23-43.

-, Underbrink, A. G. and Rossi, H. H. 1972. Mutations induced in Tradescantia by small doses of X-rays and neutrons: analysis of dose-response curves. Science 176: 916-918.

-, Schairer, L. A. and Villalobos-Pietrini, R. 1974. Comparison of somatic mutation rates induced in Tradescantia by chemical and physical mutagens. Mutat. Res. 26: 265-276.

-, Cuany, R. L., Miksche, J. P. and Schairer, L. A. 1961. Some factors affecting the response of plants to acute and chronic radiation exposures. Radiat. Bot. 1: 10-34.

Tomkins, D. J. and Grant, W. F. 1972. Comparative cytological effects of the pesticides menazon, metrobromuron and tetrachloroisophtalonitrile in Hordeum and Tradescantia. Can. J. Genet. Cytol. 14: 245-256.

Underbrink, A. G., Schairer, L. A. and Sparrow, A. H. 1973. Tradescantia stamen hairs: A radiobiological test system applicable to chemical mutagenesis. In: Chemical Mutagens: Principles and Methods for their Detection. Edited by A. Hollander. Vol. 3. Plenum N. Y. pp. 171-207.

Villalobos-Pietrini, R. and Hernández, R. 1978. Vapors of methyl alcohol induced mutations in Tradescantia clone 02. An. Inst. Biol. Univ. Nal. Autón. Méx. 49, Ser .Biol. Exp: 81-87.

Vogel, E. and Chandler, J. L. P. 1974. Mutagenicity testing of cyclamate and some pesticides in Drosophila melanogaster. Experientia 30: 621-623. 